\title{
ANALISIS AKTIVITAS DARI JAMUR ENDOFIT YANG TERDAPAT DALAM TUMBUHAN BAKAU Avicennia marina DI TASIK RIA MINAHASA
}

\author{
(Activity Analysis of Endophytes derived from Mangrove Avicennia marina Growing \\ at Tasik Ria Minahasa)
}

\author{
Jimmy Posangi'; Robert A. Bara ${ }^{2 \star}$
}

1. Bagian Farmakologi dan Terapi, FK-Unsrat

2. PS. IImu Kelautan, FPIK-Unsrat

*Email :Robert.bara@unsrat.ac.id; robertbara@yahoo.com

Endophytes can be interpreted as microbes that live in colonies in the internal tissues of plants without causing adverse effects directly on the plant. Endophytic organisms have a huge potential to be exploited as a new natural products that are useful in medicine, agriculture, and industry. On the other hand the need for new drugs that help humanity against various diseases has never end, it is due to the resistance of bacteria, viruses, pathogenic fungal infections, various types of tumors, parasites and protozoa infections in today's world population as a result of our inability to cope all these health problems. Indonesia that located in tropical area has the highest biodiversity, on the other hand, the resistance of endophytic in tropical ecosystems against pathogens and predators quite large, limited resources and very high pressures of natural selection. This raise the chances are that the endophytes in our country could have potential source of new structures with interesting biological activities to be developed as a new drug. This research is focused on the antibacterial potential. Mangrove Avicennia marina taken from Tasik Ria Beach. Endophytic fungi isolated until 2 isolates obtained pure strain of Aspergillus sp. and Acremonium sp. Both isolates were then tested its activity against pathogenic bacteria Staphylococcus aureus and Escherichia coli by using co-cultivation methods. Acremonium sp. has a higher antibacterial activity compared with the fungus Aspergillus sp. against $S$. aureus, whereas Aspergillus sp. showed antibacterial activity against E. coli.

Keywords:Endophyte, Avicennia marina, Antibacterial avtivity, Staphylococcus aureus, Escherichia coli, Acremonium sp., Aspergillus sp., co-cultivation

Endofit dapat diartikan sebagai mikroba yang hidup berkoloni dalam jaringan internal tumbuhan tanpa menyebabkan efek yang merugikan secara langsung pada tumbuhan tersebut. Organisme endofitik memiliki potensi yang sangat besar untuk dieksploitasi dan menghasilkan produk alami baru yang bermanfaat di bidang kedokteran, pertanian, dan industri. Pada sisi yang lain kebutuhan terhadap obat-obatan baru yang membantu umat manusia melawan pelbagai penyakit tidak pernah berhenti, hal ini disebabkan adanya resistensi bakteri, infeksi virus, insidensi infeksi jamur, berbagai jenis tumor, infeksi parasit dan protozoa, di dalam populasi dunia sekarang ini sebagai akibat ketidakmampuan kita untuk mengatasi tidak hanya problematika kesehatan. Indonesia sebagai daerah tropis dengan keanekaragaman hayati yang cukup besar, di lain pihak, perlawanan endofit di ekosistem daerah tropis melawan organisme patogen dan predator cukup besar, sumber daya yang terbatas dan tekanan seleksi alam sangat tinggi. Hal ini menimbulkan kemungkinan besar bahwa endofit di daerah tropis seperti di negara kita merupakan sumber struktur senyawa baru dengan aktivitas biologis yang menarik untuk dikembangkan sebagai bahan obat baru. Penelitian ini merupakan penelitian untuk mencari kandidat obat-obatan baru yang difokuskan pada kandidat bahan obat yang memiliki potensi antibakteri dan antikanker. Tumbuhan bakau Avicennia marina diambil dari Pantai Tasik Ria. Jamur endofit diisolasi hingga diperoleh 2 isolat galur murni Aspergillus sp. dan Acremonium sp. Kedua isolat kemudian diuji aktivitasnya terhadap bakteri patogen Staphylococcus aureus dan Escherichia coli dengan menggunakan metode ko-kultivasi. Acremonium sp. memiliki aktivitas antibakteri yang lebih kuat dibandingkan dengan jamur Aspergillus sp. terhadap bakteri $S$. aureus, sedangkan Aspergillus sp. menunjukkan aktivitas antibakteri yang tinggi terhadap bakteri E. coli.

Kata kunci: Endofit, Avicennia marina, antibakteri, Staphylococcus aureus , Escherichia coli, Acremonium sp., Aspergillus sp, ko-kultivasi. 


\section{Pendahuluan}

Organisme endofitik memiliki potensi yang sangat besar untuk dieksploitasi dan menghasilkan produk alami baru yang bermanfaat di bidang kedokteran, pertanian, dan industri. Sebagai gambaran, terdapat sekitar 300 ribu spesies tumbuhan tingkat tinggi di alam yang tersebar di bumi kita, masing-masing individu tumbuhan tersebut merupakan inang dari satu atau lebih mikroba endofit (Strobel et al. 2004). Saat ini saja, beberapa produk bioaktif baru diisolasi dan diidentifikasi, senyawasenyawa ini bukan hanya memiliki struktur dasar yang unik dan tetapi juga aktivitas biologis kuat (Debbab et al. 2009; Aly 2010; Proksch et al. 2010; Aly et al. 2011; Aly et al. 2011; Debbab et al. 2011; Debbab et al. 2012; Debbab et al. 2012; Ebrahim et al. 2012; Bara et al. 2013; Bara et al. 2013; Bara et al. 2013)

Keanekaragaman hayati di dalam suatu biosfer menggambarkan keragaman kandungan bahan kimia di dalamnya. Endofit yang hidup dalam tumbuhan memiliki fungsi untuk mempertahankan eksistensi dari tumbuhan inang untuk dapat bertahan hidup dan mempertahankan diri dari organisme patogen dan predator utama mereka. Hal ini membuat organisme endofit berevolusi secara konstan untuk menghaslkan senyawa-senyawa kimia baru untuk melindungi inang mereka. Daerah tropis adalah contoh luar biasa dari jenis lingkungan ini. Dalam ekosistem yang terdapat di daerah ini, perlawanan endofit melawan organisme patogen dan predator cukup besar, sumber daya yang terbatas dan tekanan seleksi alam sangat tinggi (Strobel et al. 2004). Hal ini menimbulkan kemungkinan besar bahwa endophytes di daerah tropis seperti di negara kita merupakan sumber struktur senyawa baru dengan aktivitas biologis yang menarik.

Lingkungan laut merupakan sumber yang besar dari produk alam yang memiliki struktur yang unik yang umumnya terkonsentrasi pada sponge, tunikata, bryozoa, dan moluska yang merupakan organisme yang hidup dalam kolom air. Sejumlah besar dari senyawa-senyawa ini menunjukkan aktivitas farmakologi yang kuat dan merupakan kandidat yang menarik untuk bahan obat-obatan baru terutama pada area penelitian antikanker dan antimikroba. Senyawa-senyawa lainnya telah dikembangkan sebagai kandidat obat analgesik (sebagai contoh ziconotid yang diperoleh dari moluska spesies Conus magus) atau untuk mengobati inflamasi. Sejumlah produk alami yang diperoleh dari organisme bahari ini menunjukkan kesamaan struktur kimia yang langsung dengan metabolit yang diproduksi oleh mikroba. Yang memungkinkan mikroorganisme ini (endosimbion berupa jamur, bakteri dan alga mikro) setidaknya terlibat dalam proses biosintesis senyawasenyawa yang diproduksi oleh organisme laut ini atau merupakan sumber sebenarnya dari senyawa tersebut. Hal ini tidak hanya berlaku dalam lingkungan bawah laut itu sendiri tetapi juga lingkungan yang berbatasan dengan laut termasuk di dalamnya ekosistem mangrove. Indonesia sebagai negara yang memiliki keanekaragaman hayati yang tinggi memiliki peluang yang cukup besar untuk penemuan bahan kandidat obat. Di lain pihak, penelitian tentang fungi endofitik terutama yang berasal dari mangrove sebagai penghasil senyawa bahan alami di Indonesia masih sangatlah terbatas.

Avicennia marina (Forsk.) Vierh. Umumnya dikenal sebagai tumbuhan bakau putih atau abu-abu. Belakangan, tumbuhan ini diklasifikasikan kembali sebagai genus tersendiri dari sub-famili Avicenniodeae dalam famili Acanthaceae (Duke 1991). Mangrove ini terdistribusi mulai dari daerah tropis sampai dengan daerah subtropis. Di perairan Sulawesi Utara sendiri, mangrove ini mendominasi daerah pasang surut di sepanjang garis pantai. Daun dan kulit dari A. marina digunakan oleh penduduk lokal Pulau Mantehage untuk mengobati diare dan abses (Madjowa et al. 2000). Penelitian sebelumnya dari tumbuhan yang berasal 
dari genus yang sama menunjukan adanya senyawa derivat naftoquinon (Ito et al. 2000), glikosida iridoid (Koenig and Rimpler 1985), diterpenoid ( $\mathrm{Li}$ et al. 2008) dan flavonoid (Feng et al. 2006). Sedangkan penelitian potensi endofit untuk dapat dikembangkan sebagai produsen kandidat obat baru yang terdapat dari genus yang sama masih belum dikembangkan secara mendalam.

Penelitian terbaru yang dilakukan oleh penulis terhadap jamur endofitik Botryosphaeria australis yang diisolasi dari mangrove Avicennia marina yang berasal dari Profinsi Hainan, Republik Rakyat China diperoleh senyawa baru Botryosphaenin dari kelas senyawa naftoquinon, bersamasama dengan 5 senyawa yang telah dikenal botriosterpen, 5-hidroksi 2,7dimetoksinaftalen-1,4-dion dan derivatnya, 6-etil-5-hidroksi-2,7-dimetoksinaftalen-1,4dion, O-metilaspmenon, O-metilasparienon and 5-(karboksimetil)-7-hidroksi-1,4adimetil-6-metilendekahidronaftalen-1-asam karbosiklat. Senyawa baru yang diisolasi menunjukkan bioaktivitas terhadap bakteri pathogen Staphylococcus aureus resisten, beberapa spesies Streptococcus dan Bacillus subtilis dan juga menunjukkan aktivitas terhadap sel eukariot THP-1 (human leukemia monocyte) and BALB/3T3 (mouse embryonic fibroblast).

Telah dilakukan penelitian untuk mengetahui potensi antibakteri jamur endofit yang diisolasi dari mangrove Avicennia marina yang tumbuh di Perairan Manado (ex-situ). Secara umum, jamur endofit dikultur dalam media kaya karbohidrat, selanjutnya ditumbuhkan bersama dengan bakteri uji untu melihat potensi antibakteri dari isolat tersebut.

\section{Metode Penelitian}

Tumbuhan bakau jenis Avicennia marina di ambil dari perairan Pantai Tasik Ria. Jamur endofit diisolasi dari dalam jaringan dalam dari tumbuhan dengan cara sebagai berikut. Potongan akar dari tumbuhan direndam dalam etanol $70 \%$ selama 30 detik untuk menghindari kontaminasi silang jamur epifit dan di potong dengan metode septikaseptik. Potongan ini selanjutnya diletakkan di atas permukaan malt agar di cawan petri. Kloramfenikol $0.2 \mathrm{~g} / \mathrm{L}$ sebelumnya di tambahkan ke dalam media malt Potato Dextrose Agar (PDA) untuk mencegah kontaminasi silang bakteri. Kontrol negatif di pakai untuk melihat pertumbuhan jamur epifit yang terdapat di permukaan tumbuhan. Jamur mulai tumbuh dari potongan setelah 3-7 hari. Selanjutnya dilakukan pemurnian endofit yang bertujuan untuk memisahkan koloni endofit dengan mengamati perbedaan morfologi. Purifikasi jamur dilakukan dengan cara menusuk miselia jamur yang tumbuh pada bagian terjauh dengan menggunakan kawat ose steril, selanjutnya bagian dari jamur tersebut dipindahkan kembali ke media PDA steril. Hal yang sama juga dilakukan pada miselia dengan morfologi yang berbeda.

Uji antibakteri dari jamur endofit dilakukan dengan metode Kirby-Bauer (Boyd 1995; Koneman et al 1992, Lay 1994) yang dimodifikasi oleh (Nainggolan 2000). Pengujian aktivitas ini dilakukan dengan menanam potongan agar dari miselium isolat jamur pada cawan petri yang berisi media kombinasi yang merupakan paduan antara media PDA dan NA dengan jarak yang sama. Sebelumnya bakteri uji digores pada permukaan media. Hal ini dilakukan dengan menumbuhkan bersama bakteri uji dan isolat jamur endofit dengan bakteri uji pada media kombinasi. Langkah ini dikenal dengan istilah ko-kultivasi. Ciprofloxacin sebagai kontrol positif dilarutkan sebanyak $2 \mathrm{mg} / \mathrm{ml}$. Selanjutnya diinkubasi pada suhu ruang selama $1 \times 24$ jam. Pengukuran zona hambat dilakukan mengukur diameter daerah jernih yang terbentuk.

\section{HASIL DAN PEMBAHASAN}

Miselia jamur yang telah tumbuh pada media PDA kemudian secara bertahap dimurnikan satu-persatu selanjutnya dipindahkan ke media tersebut di atas pada cawan petri lainnya. Pemurnian ini 
dilakukan dengan melihat perbedaan karakteristik morfologi miselia dari tiap jamur yang diisolasi.

Dari tahapan pemurnian jamur endofit akar bakau $A$. marina diperoleh dua jenis isolat jamur dengan karakteristik muselium berwarna hitam, pengamatan lanjut dari jamur ini disimpulkan merupakan jenis jamur yang menyerupai-Aspergillus (Aspergillus-like fungus) selanjutnya disebut sebagai Aspergillus sp., sedangkan isolat jamur berikutnya memiliki karakteristik warna miselium putih, pada pengamatan lanjut dari jamur ini disimpulkan merupakan jenis jamur yang menyerupai-Acremonium (Acremonium-like fungus) yang selanjutnya disebut sebagai Acremonium sp., kedua jamur kemudian dikultur kembali pada media PDA. Dalam penelitian yang dilakukan oleh (Noverita et al. 2009), jamur yang diisolasi dari daun lebih banyak dari pada yang diisolasi dari rimpang atau akar tumbuhan. Hal ini diduga karena lebih mudah mendapatkan nutrisi dari daun dibandingkan dari rimpang. Jamur endofit yang diisolasi dari akar bakau $A$. marina dapat dilihat pada Gambar 1.

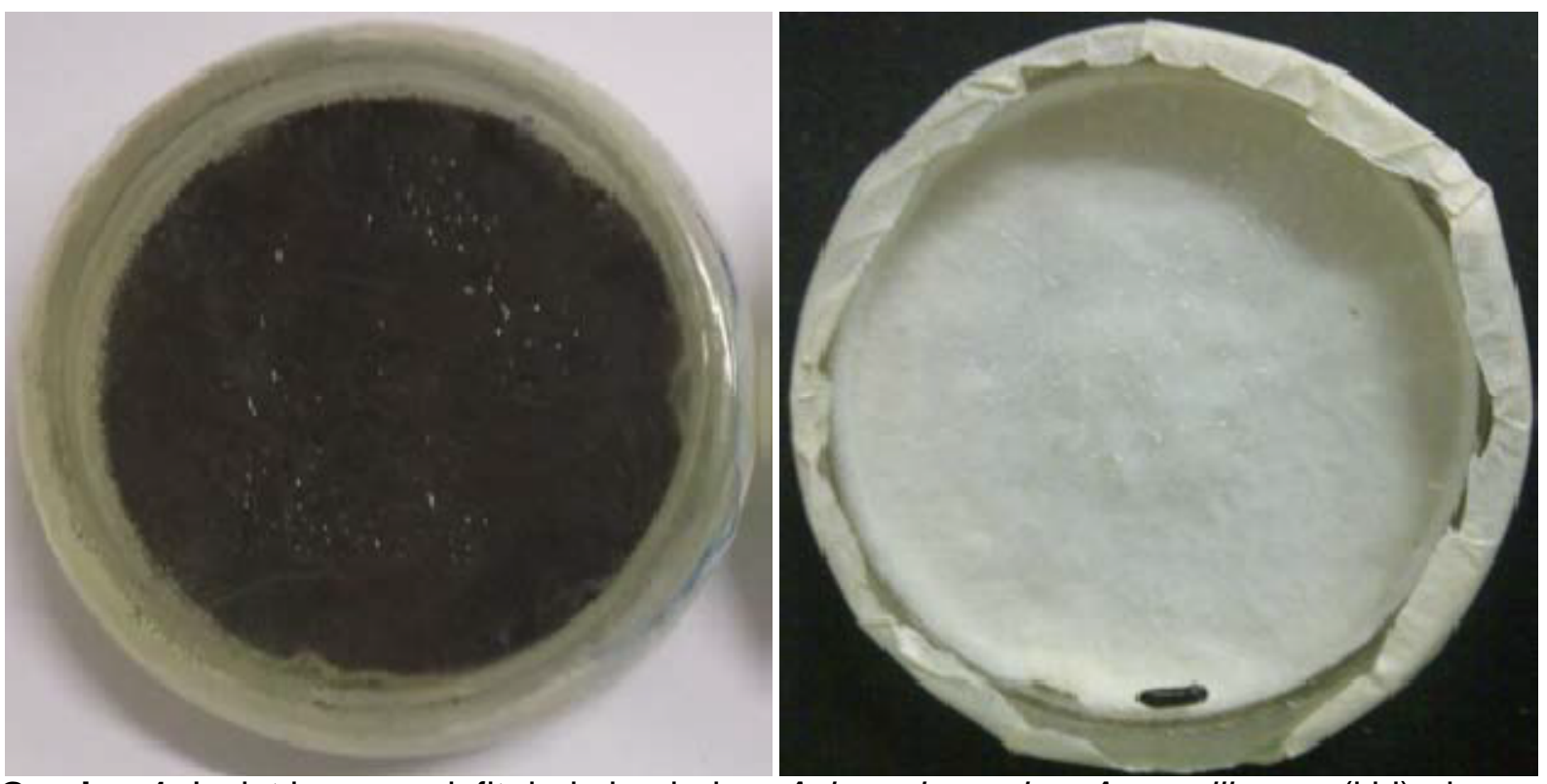

Gambar 1. Isolat jamur endofit dari akar bakau Avicennia marina, Aspergillus sp. (kiri), dan Acremonium sp.(kanan).

Setelah diperoleh isolat yang murni, langkah selanjutnya yang dilakukan yaitu melakukan skrining ada tidaknya aktivitas antibakteri pada kedua isolat jamur endofit yang diisolasi dari tumbuhan A. marina. Hal ini dilakukan dengan menumbuhkan bersama bakteri uji dan isolat jamur endofit dengan bakteri uji pada media kombinasi. Langkah ini dikenal dengan istilah ko- kultivasi. Gambar 2 dan 3 menunjukkan adanya aktivitas antibakteri kedua isolat jamur endofit yang diisolasi dari akar bakau A. marina terhadap bakteri uji Staphylococcus aureus dan Escherichia coli sedangkan Gambar 4 merupakan rata-rata zona hambat yang dihasilkan oleh kedua jamur endofit terhadap bakteri uji tersebut di atas. 

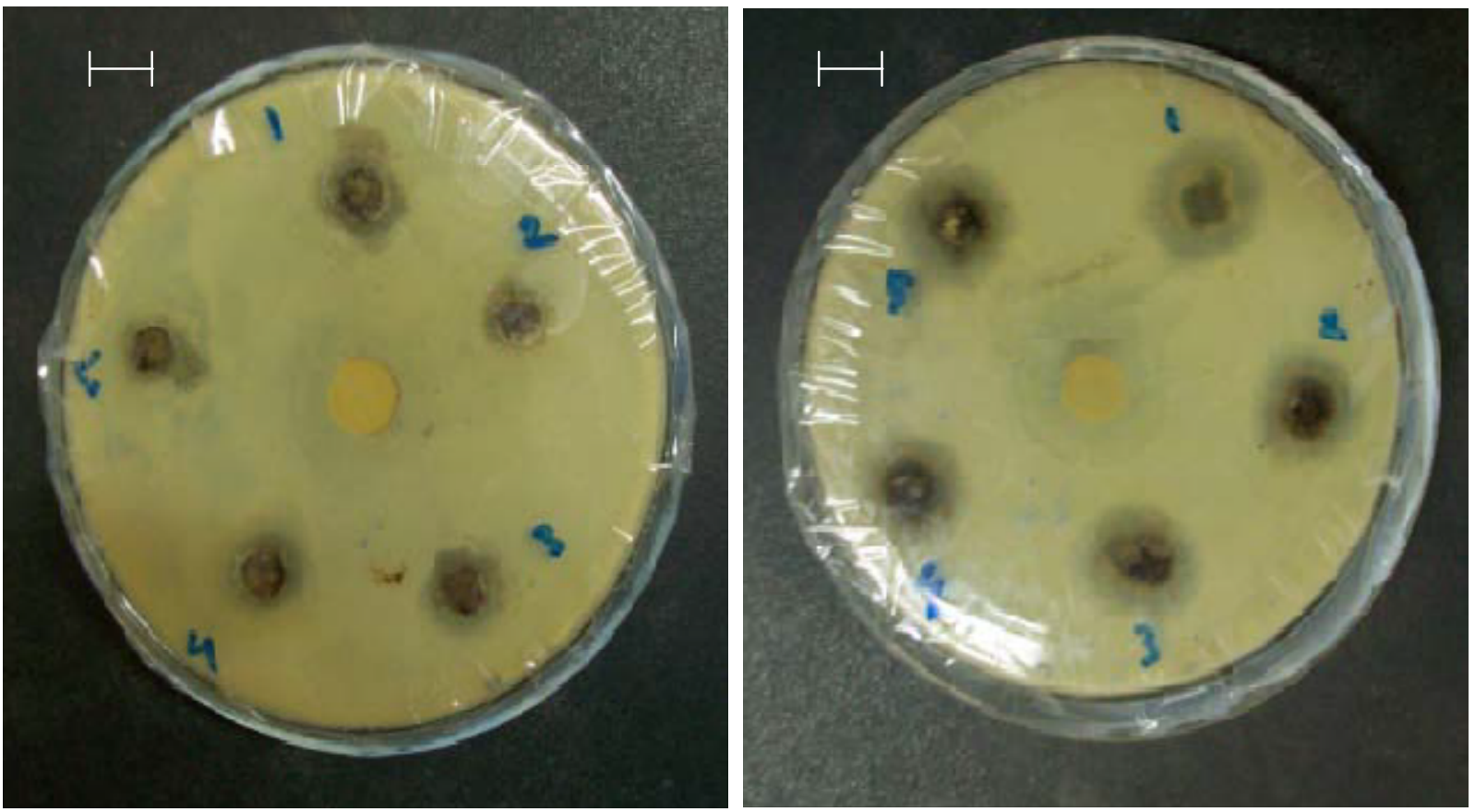

Gambar 2. Zona hambat jamur Aspergillus sp. terhadap bakteri uji Staphylococcus aureus (kiri) dan Escherichia coli (kanan). Skala $10 \mathrm{~mm}$
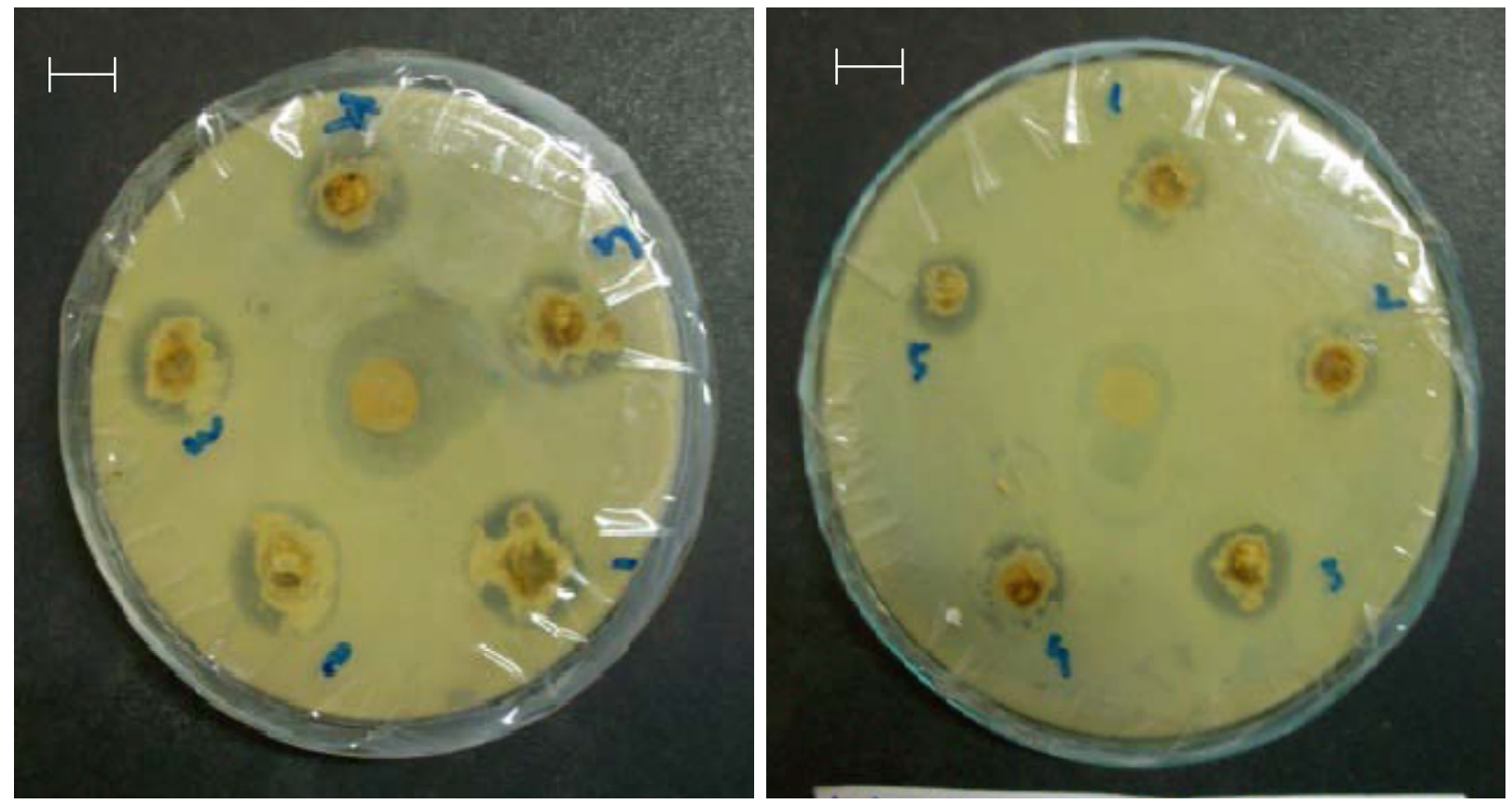

Gambar 3. Zona hambat jamur Acremonium sp. terhadap bakteri uji Staphylococcus aureus (kiri) dan Escherichia coli (kanan). Skala $10 \mathrm{~mm}$. 


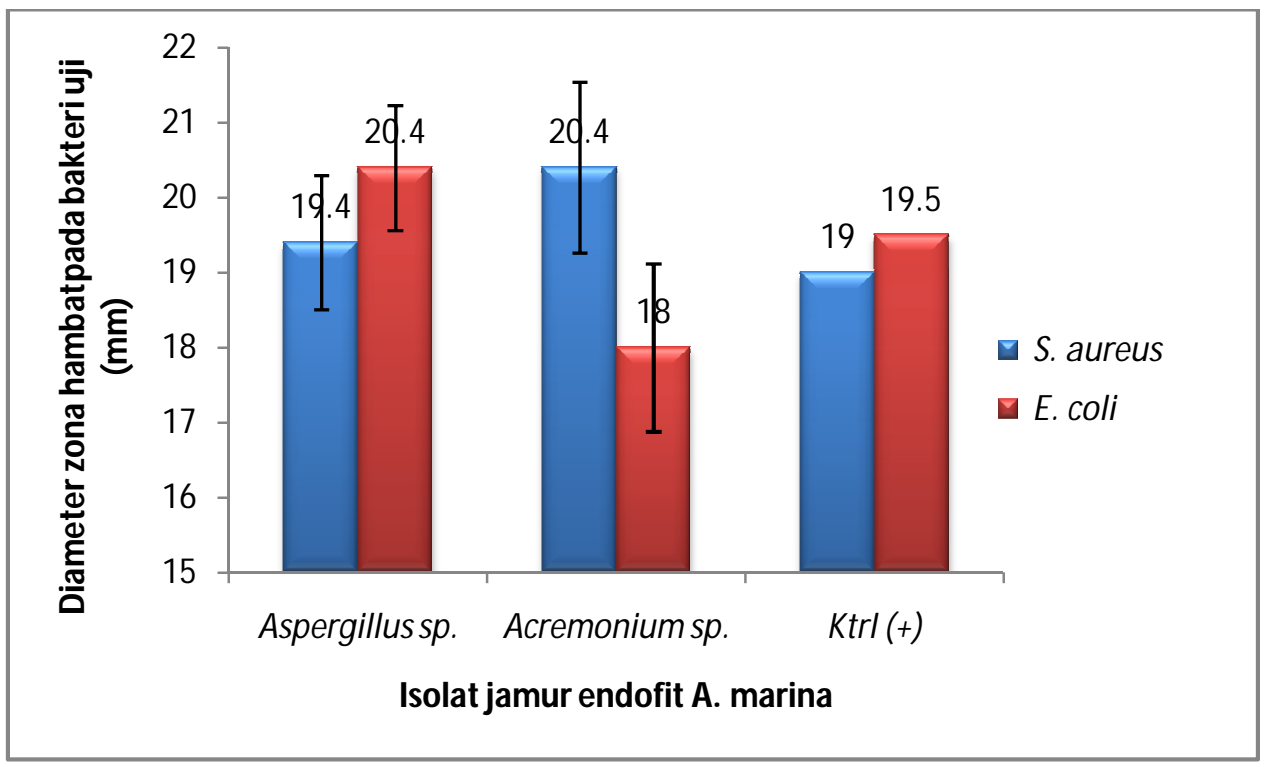

Gambar 4. Grafik rata-rata zona hambat yang dihasilkan oleh kedua jamur endofit terhadap bakteri uji Staphylococcus aureus dan Escherichia coli

Pada pengukuran diameter zona hambat (Gambar 4) didapatkan rata-rata daya hambat pertumbuhan bakteri uji $S$. aureus yang bersifat Gram positif pada jamur Acremonium sp. lebih tinggi bila dibandingkan dengan jamur Aspergillus sp. hal ini diduga oleh beberapa hal antara lain konsentrasi tumbuh pada kedua jamur yang berbeda di mana pada pertumbuhan sel Acremonium sp. lebih signifikan dibandingkan dengan jamur Aspergillus sp. dugaan lainnya konsentrasi senyawa antibakteri yang dihasilkan oleh kedua isolat yang berbeda, atau dapat pula diakibatkan oleh perbedaan jenis senyawa yang dihasilkan. Di sisi yang lain, jamur Aspergillus sp. menunjukkan aktivitas aktibakteri yang kuat terhadap bakteri uji $E$. coli jika dibandingkan dengan isolat Acremonium sp. hal ini menunjukkan bahwa kandungan senyawa antibakteri dari isolat Aspergillus sp. lebih bersifat spesifik ke Gram negatif dibandingkan dengan isolat Acremonium sp. hal ini sangat menguntungkan untuk diteliti lebih lanjut mengenai kandungan senyawa aktif yang dihasilkan oleh isolat Aspergillus sp. sehingga diperoleh senyawa yang murni.
Sejauh ini pengendalian infeksi Gram negatif sering kali menjadi kendala dalam dunia kedokteran modern, hal ini diakibatkan oleh karakteristik bakteri kelompok Gram negatif yang memiliki dinding peptidoglikan yang cukup padat dan kompak sehingga menghambat proses internalisasi senyawa obat untuk mampu mempengaruhi mekanisme selular dari bakteri. Di samping adanya "efflux-pump mechanism", suatu mekanisme untuk mengeluarkan senyawa-senyawa yang tidak dibutuhkan dalam proses-proses biotransformasi seluler bakteri melalui sistem sekresi mereka (Poole 2007).

Kontrol positif siprofloksasin memiliki mekanisme aksi menghambat pertumbuhan bakteri dengan mekanisme menghambat terbentuknya enzim DNA girase atau lebih dikenal dengan enzim topoisomerase DNA yang dibutuhkan bakteri pada proses replikasi, transkripsi, perbaikan DNA yang rusak dan juga proses rekombinasi DNA bakteri.

Adanya senyawa-senyawa antibakteri dari kedua isolat juga diperkuat dengan ditemukannya senyawa cytocidal, 
chlovalicin, isocoumarins, dan senyawa taxol yang berfungsi sebagai antibiotik, anti inflamasi, anti alergi dan anti kanker. Senyawa cytocidal dan chlovalicin di temukan dalam jamur endofit yang diisolasi dari tumbuhan bakau Kandelia candel. Senyawa isocoumarins di temukan dalam jamur endofit yang diisolasi dari daun muda tumbuhan bakau Avicennia marina yang ditemukan di Pearl River Estuary, Tiongkok Selatan (Huang et al. 2007). Senyawa turunan indol dan diketopiperazin yang memiliki aktivitas antibakteri dihasilkan oleh jamur Penicillium chrysogenum, endofit dari bakau Porteresia coarctata (Roxb.) (Devi et al. 2012). Penulis juga menemukan senyawa baru dengan sifat antibakteri yang kuat yang diisolasi dari jamur endofit Botryosphaeria australis dari tumbuhan bakau $A$. marina yang tumbuh di Provinsi Hainan, Tiongkok (Bara et al. 2013). Senyawa-senyawa yang dihasilkan jamur endofit yang hidup secara ko-eksisten dengan tumbuhan bakau kemungkinan merupakan mekanisme perlindungan diri terhadap mikroorganisme patogen seperti bakteri dan proses predasi terhadap tumbuhan tersebut. Senyawa yang dihasilkan untuk mekanisme perlindungan diri ini lah yang bisa dimanfaatkan oleh manusia sebagai kandidat obat.

\section{KESIMPULAN}

Berdasarkan hasil penelitian yang telah dilakukan maka dapat diambil beberapa kesimpulan sebagai berikut.

1. Diperoleh dua isolat jamur endofit yang diisolasi dari akar bakau Avicennia marina, yaitu Aspergillus sp. dan Acremonium sp. kedua isolat menunjukkan daya hambat pertumbuhan bakteri uji Staphylococcus aureus dan Escherichia coli.

2. Acremonium sp. memiliki aktivitas antibakteri yang lebih kuat dibandingkan dengan jamur Aspergillus sp. terhadap bakteri $S$. aureus, di sisi yang lain jamur Aspergillus sp. menunjukkan aktivitas antibakteri yang tinggi terhadap bakteri $E$. coli yang merupakan bakteri Gram negatif.

\section{Daftar Pustaka}

Aly, A. H. Protein kinase inhibitors and other cytotoxic metabolites from the fungal endophyte Stemphylium botryosum isolated from Chenopodium album. Mycosphere. 2010. 1. 2. 153

Aly, A. H., Debbab, A., Clements, C., Edrada-Ebel, R., Orlikova, B., Diederich, M., Wray, V., Lin, W. and Proksch, P. NF kappa B inhibitors and antitrypanosomal metabolites from endophytic fungus Penicillium sp. isolated from Limonium tubiflorum. Bioorganic \&amp; Medicinal Chemistry. 2011. 19. 1. 414-421

Aly, A. H., Debbab, A. and Proksch, P. Fungal endophytes: unique plant inhabitants with great promises. Applied Microbiology and Biotechnology. 2011. 90. 6. 18291845

Bara, R., Aly, A. H., Pretsch, A., Wray, V., Wang, B., Proksch, P. and Debbab, A. (2013). Antibiotically active metabolites from Talaromyces wortmannii, an endophyte of Aloe vera.

Bara, R., Aly, A. H., Wray, V., Lin, W., Proksch, P. and Debbab, A. Talaromins $A$ and $B$, new cyclic peptides from the endophytic fungus Talaromyces wortmannii.

Tetrahedron Letters. 2013. 54. 13. 1686-1689

Bara, R., Zerfass, I., Aly, A. H., GoldbachGecke, H., Raghavan, V., Sass, P.,

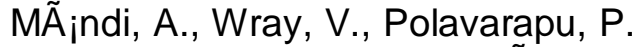
L., Pretsch, A., Lin, W., Kurt $\tilde{A}_{j n}, T$., Debbab, A., Brötz-Oesterhelt, H. and Proksch, P. Atropisomeric Dihydroanthracenones as Inhibitors of Multiresistant Staphylococcus aureus. Journal of Medicinal Chemistry. 2013. 56. 8. 3257-3272.

Bara, R. A., Zerfaß, I., Lai, D., Lin, W., Debbab, A., Brötz-Oesterelt, H. and 
Proksch, P. New Natural Product from Botryosphaeria australis, an Endophyte from Mangrove Avicennia marina. Squalen Bulletin of Marine \& Fisheries Postharvest \& Biotechnology. 2013. 8. 3. 139-145.

Debbab, A., Aly, A. and Proksch, P. Bioactive secondary metabolites from endophytes and associated marine derived fungi. Fungal Diversity. 2011. 49.1.1-12

Debbab, A., Aly, A. and Proksch, P. Endophytes and associated marine derived fungi-ecological and chemical perspectives. Fungal Diversity. 2012. 57. 1. 45-83

Debbab, A., Aly, A. H., Edrada-Ebel, R., Wray, V., Müller, W. E. G., Totzke, F., Zirrgiebel, U., Schälchtele, C., Kubbutat, M. H. G., Lin, W. H., Mosaddak, M., Hakiki, A., Proksch, $P$. and Ebel, R. Bioactive metabolites from the endophytic fungus Stemphylium globuliferum isolated from Mentha pulegium. Journal of Natural Products. 2009. 72. 4. 626-631

Debbab, A., Aly, A. H., Edrada-Ebel, R., Wray, V., Pretsch, A., Pescitelli, G., Kurtan, T. and Proksch, P. New Anthracene Derivatives - Structure Elucidation and Antimicrobial Activity. European Journal of Organic Chemistry. 2012. 7. 13511359

Devi, P., Rodrigues, C., Naik, C. and D'Souza, L. Isolation and Characterization of Antibacterial Compound from a MangroveEndophytic Fungus, Penicillium chrysogenum MTCC 5108. Indian Journal of Microbiology. 2012. 52. 4. 617.

Duke, N. C. A systematic revision of the mangrove genus Avicennia (Avicenniaceae) in Australasia. Austalian Systematic Botany. 1991. 4. 229-334.

Ebrahim, W., Aly, A. H., Mándi, A., Totzke, F., Kubbutat, M. H. G., Wray, V., Lin, W.-H., Dai, H., Proksch, P., Kurtán,
T. and Debbab, A. Decalactone derivatives from Corynespora cassiicola, an endophytic fungus of the mangrove plant Laguncularia racemosa. European Journal of Organic Chemistry. 2012. 2012. 18. 3476-3484.

Feng, Y., Li, X. M., Duan, X. J. and Wang, B. G. Iridoid glucosides and flavones from the aerial parts of Avicennia marina. . Chem Biodivers 2006. 3. 799-806.

Huang, H., She, Z., Lin, Y., Vrijmoed, L. L. P. and Lin, W. Cyclic Peptides from an Endophytic Fungus Obtained from a Mangrove Leaf (Kandelia cande/). Journal of Natural Products. 2007. 70. 11. 1696-1699.

Ito, C., Katsuno, S., Kondo, Y., Tan, H.-W. and Furukawa, $H$. Chemical constituents of Avicennia alba. Isolation and structural elucidation of new naphthoquinones and their analogues. . Chem Pharm Bull. 2000. 48:. 339-343.

Koenig, $G$. and Rimpler, $H$. Iridoid glucosides in Avicennia marina. Phytochemistry. 1985. 24. 1245-8.

Li, H., Xueshi, H., Dahse, H. M., Moellmann, U., Grabley, S., Wenhan, L. and Sattler, I. (2008). New Abietane Diterpenoids from the Mangrove : Avicennia marina. Stuttgart, ALLEMAGNE, Thieme.

Madjowa, H., Posangi, J. and Rompas, R. M. Studi etnofarmakologi organisme laut yang terdapat dari Pulau Mantehage. Skripsi Fakultas Perikanan dan IImu Kelautan, Unsrat. 2000. 90 hal.

Nainggolan, J. I. Metode dan Teknik Penelitian Antimikroba Antibakteri. diperoleh dengan wawancara pribadi dengan narasumber. 2000.

Noverita, Dinah Fitria and Sinaga, E. Isolasi dan uji aktivitas antibakteri jamur endofit dari daun dan rimpang Zingiber ottensii Val.. 2009. 4.

Poole, K. Efflux pumps as antimicrobial resistance mechanisms. Annals of Medicine. 2007. 39. 3. 162-176 
Proksch, P., Putz, A., Ortlepp, S., Kjer, J. and Bayer, M. Bioactive natural products from marine sponges and fungal endophytes. Phytochemistry Reviews. 2010. 9. 4. 475-489.

Strobel, G., Daisy, B., Castillo, U. and Harper, J. Natural Products from endophytic microorganisms. Journal of Natural Products. 2004. 67. 2. 257-268. 